\title{
Trace metals assessment in water, sediment, mussel and seagrass species - Validation of the the use of Posidonia oceanica as a metal biomonitor
}

\author{
Lafabrie C. ${ }^{{ }^{*}}$, Pergent G. ${ }^{a}$, Kantin R. ${ }^{b}$, Pergent-Martini C. ${ }^{a}$, Gonzalez J.-L. ${ }^{b}$ \\ aUniversity of Corsica, Faculty of Sciences, Equipe Ecosystèmes Littoraux, BP 52, 20250 Corte, France \\ bIFREMER, 83507 La Seyne-sur-Mer, France \\ * Corresponding author. Phone: +33 495450 075; fax: +33 495462441. \\ E-mail address: lafabrie@univ-corse.fr (C. Lafabrie).
}

\begin{abstract}
The accumulation of trace metals $(\mathrm{Cd}, \mathrm{Co}, \mathrm{Cr}, \mathrm{Hg}, \mathrm{Ni}$ and $\mathrm{Pb}$ ) was measured in water, sediment, the mussel Mytilus galloprovincialis and the seagrass Posidonia oceanica. Samples were collected in three locations of the north-western Mediterranean (Canari, Livorno and Porto-Torres) which present different levels and sources of human impact. Analyses in the different compartments (water, sediment, Mytilus galloprovincialis and Posidonia oceanica) have allowed to identify Canari as the most $\mathrm{Cd}, \mathrm{Co}, \mathrm{Cr}$ and $\mathrm{Ni}$ contaminated site; Livorno as the most $\mathrm{Hg}$ contaminated and Porto-Torres as the most $\mathrm{Pb}$ contaminated. Furthermore, for the first time metal concentrations found in Posidonia oceanica have been compared with those found in the water column, in the sediment and in the recognized metal bio-indicator species Mytilus galloprovincialis and the results obtained have led to the same conclusions. Thus, this study allows to validate the use of Posidonia oceanica as metal biomonitor of coastal waters.
\end{abstract}

Keywords: metal contamination, biomonitoring, seawater, sediment, marine organisms, Mediterranean Sea 


\section{Introduction}

The continental shelf constitutes the most important zone of the marine environment as far as human activities are concerned, as it contains the main source of living marine resources (Castro et al., 1999; Usero et al., 2005) and as it is the area that is most concerned by humaninduced changes (Zoller, 2006). The coastal part of this continental shelf is the most sensitive, as it receives large amounts of contaminants introduced by domestic, industrial and agricultural activities, directly or via rivers or through atmospheric deposition (Zoller and Hushan, 2000; Usero et al., 2005). In most cases, the impact and synergistic effects of contaminants on marine ecosystem are poorly known (Zoller, 2006). The early identification of inorganic contaminants such as trace metals, which are all toxic above a specific threshold of bioavailable level (Kucuksezgin et al., 2006), is essential to avoid damage to marine biocenoses (Girotti et al., 2006).

The comparison of metal contamination in different aquatic environments is possible by analysis of water (Davison and Zhang, 1994; Manfra and Accornero, 2005; Stark et al., 2006), sediment (Calmano et al., 1996; Acevedo-Figueroa et al., 2005; Tankere-Muller et al., 2006) and indigenous biota (Rainbow and Phillips, 1993; Goldberg and Bertine, 2000; Pergent-Martini and Pergent, 2000; Ferrat et al., 2003b). Bioaccumulation studies led to the adoption of the bioindicator concept (Langston and Spence, 1995). Monitoring networks, mostly based on bivalves (O'Connor, 1996; Goldberg and Bertine, 2000; Andral et al., 2004; Morillo et al., 2005; Usero et al., 2005), have been developed in order to evaluate the marine environment quality. Seagrasses are increasingly used as indicators of chemical contaminations of coastal regions (see synthesis in Ferrat et al., 2003b). In the Mediterranean Sea, the endemic species Posidonia oceanica (L.) Delile is often considered a useful metal bio-indicator (Capiomont et al., 2000; see synthesis in Pergent-Martini and Pergent, 2000; Campanella et al., 2001; Ferrat et al., 2003a).

The aim of this study is three fold: (i) first, to determine trace metals concentrations in water, sediment, the mussel Mytilus galloprovincialis (L) Lamarck, 1819 and the seagrass Posidonia oceanica in three Mediterranean locations; (ii) second, to compare, for the first time, the metal concentrations in these different compartments (water, sediment, Mytilus galloprovincialis, Posidonia oceanica); and (iii) third, to evaluate the relevance of Posidonia oceanica as a metal bio-indicator.

\section{Materials and methods}

\subsection{Sampling locations}

Samples were collected in three stations, selected randomly, in three north-western Mediterranean locations (Canari, Livorno and Porto-Torres; Figure 1) situated in proximity of different human-induced impact activities.

Canari (Corsica-France), on the west coast of the Cap Corse, is located next to a previous asbestos mine which discharged, between 1948 and 1965, more than 11 million tons of serpentinite rubble directly into the sea (Bernier et al., 1997). Livorno (Toscana-Italy) is situated in proximity of the chemical plant of Rosignano Solvay which discharged, until the last decade, about $8000 \mathrm{~m}^{3} \cdot \mathrm{h}^{-1}$ of industrial waste into the sea (Petrelli et al. 1979; Balestri et al., 2004). Porto-Torres (Sardinia-Italy) is situated close to the Porto-Torres industrial harbour which is one of the most important in Sardinia in terms of hydrocarbons and petrochemical products traffic (De Luca et al., 2004). In January 2004, a hazardous materials accident occurred in this harbour (tanker unloading benzene, loss of ship; CEDRE, 2004; Ronza et al., 2006). Samples were collected in summer 2004 in Canari and Porto-Torres, and in summer 2005 in Livorno.

\subsection{Sampling method, sample preparation and trace metals analyses (cadmium: Cd; cobalt: C; chromium: Cr; mercury: $\mathrm{Hg}$; nickel: $\mathrm{Ni}$ and lead: $\mathrm{Pb}$ )}

Diffusive gradients in thin films (DGT) sampling technique, based on diffusion of metals through a diffusive layer until a binding phase where they are concentrated (Davison and Zhang, 1994; Zhang and Davison, 2000), was used to determine seawater metal 
concentrations. DGT units consist of polyacrylamide hydrogel diffusion layers ( $0.76 \mathrm{~mm}$ thick), Chelex 100 impregnated binding phases $(0.40 \mathrm{~mm}$ thick) and nylon DGT holders (DGT Research Ltd. UK). They were assembled with $0.45 \mu \mathrm{m}$ pore-size cellulose acetate filters, used as covering membranes. DGT units were positioned at approximately $2 \mathrm{~m}$ above the bottom of the water column and were deployed for about 24h. Elution of metals, from the Chelex 100 binding phase, was carried out by immersion in $1.0 \mathrm{M} \mathrm{HNO}_{3}$ (Suprapure). Metal analysis was carried out by inductively coupled plasma mass spectrometry (ICP-MS).

Superficial sediment (80 to $500 \mathrm{~g}$ dry wt.) was collected in PVC cores by scuba divers, in the vicinity of the Posidonia oceanica meadow. The fraction of the sediment inferior to $2 \mathrm{~mm}$ was frozen, lyophilised and analysed by atomic absorption spectrometry, with quality assurance procedures, at the Laboratory of Rouen / ETSA (France).

Transplanted mussels were stored in conchylicultural pouches and immersed $6 \mathrm{~m}$ below the surface, above Posidonia oceanica meadow. Immersion period lasted three months and occurred during the mussel sexual dormancy period in order to improve immersion conditions and to minimize tissue-growth variations (Andral et al., 2004). Mussels were opened raw, the flesh scraped out of the shells, which were then frozen, lyophilised, reduced to powder and analysed by atomic absorption spectrometry with quality assurance procedures at the Laboratory of Rouen / ETSA (France).

Posidonia oceanica shoots were collected at $10 \pm 1 \mathrm{~m}$ depth by scuba divers. Only the blades (Giraud, 1979) were analysed, as it has been previously reported that most trace metals accumulate preferentially in blades (Lafabrie et al., 2007). Epiphytes and sediment were removed from the blades using a glass strip. Samples were rinsed (ultrapure water), frozen, lyophilised and reduced to powder. For $\mathrm{Hg}$ analyses, $50 \mathrm{mg}$ of each sample was weighed in a Teflon digestion vessel $\mathrm{CEM}^{\circledR}$ ACV of $100 \mathrm{ml}$ (CEM Corporation, USA). $5 \mathrm{ml}$ of $69 \% \mathrm{HNO}_{3}$ (Normapur) and $1 \mathrm{ml}$ of $\mathrm{H}_{2} \mathrm{O}_{2} 30 \%$ (Normapur) were added. The vessels were sealed and placed into the $\mathrm{CEM}^{\circledR}$ MARS 5 chamber $\left(20\right.$ minutes at $200^{\circ} \mathrm{C}$ and 20 minutes of cooling). The content of each vessel was poured into $25 \mathrm{ml}$ volumetric flasks and diluted to volume with ultrapure water and then transferred to $60 \mathrm{ml}$ polypropylene flasks. Mineralized samples were analysed with a cold vapour atomic absorption spectrometer (CV-AAS - Perkin Elmer ${ }^{\circledR}$ ). The standard addition method was applied for calibration. Calibration standards were prepared from a mercury standard solution $1000 \mathrm{mg}^{-1} \mathrm{~L}^{-1} \mathrm{Cd}, \mathrm{Co}, \mathrm{Cr}, \mathrm{Ni}$ and $\mathrm{Pb}$ were analysed by atomic absorption spectrometry with quality assurance procedures at the Laboratory of Rouen / ETSA (France).

Limit of detection was defined as three times the standard deviation from the mean blank (US Environmental Protection Agency, 2000). The instrumentation limits of detection were between 0.3 and $2 \mu \mathrm{g} \cdot \mathrm{L}^{-1}$. The standard addition method was applied for calibrations and calibration standards were prepared from standard solutions of $1000 \mathrm{mg} \cdot \mathrm{L}^{-1}$ (Merck). The analytic procedure was verified using certified reference material (Lagarosiphon major, CRM 60; Community Bureau of Reference - Commission of the European Communities; Table 1).

\subsection{Statistical analysis}

For metal concentrations in sediment, differences between locations were evaluated by Kruskal-Wallis test. For metal concentrations in Mytilus galloprovincialis and Posidonia oceanica, differences between organisms and between locations were determined by a two-way analysis of variance (ANOVA) followed by the post-hoc test of Tukey. Correlations between metal concentrations in Posidonia oceanica and sediment were performed by analysis of Pearson's correlations.

\section{Results}

\subsection{DGT units (DGTs)}

The highest $\mathrm{Cd}$, Co and Ni concentrations are recorded in Canari whereas the highest $\mathrm{Cr}$ concentration found in Livorno and the highest $\mathrm{Pb}$ concentration in Porto-Torres (Table 2). 


\subsection{Sediment}

The highest $\mathrm{Co}, \mathrm{Cr}$ and $\mathrm{Ni}$ concentrations are recorded in Canari $(P<0.05)$ whereas the highest $\mathrm{Cd}, \mathrm{Hg}$ and $\mathrm{Pb}$ concentrations are recorded in Livorno $(P<0.05$; Table 3$)$.

\subsection{Organisms}

Metal concentrations in Mytilus galloprovincialis and Posidonia oceanica in the different locations are shown in Table 4.

$\mathrm{Cd}, \mathrm{Co}, \mathrm{Ni}$ and $\mathrm{Pb}$ concentrations are significantly higher $(P<0.05)$ in Posidonia oceanica than in Mytilus galloprovincialis whereas $\mathrm{Cr}$ and $\mathrm{Hg}$ concentrations are significantly higher $(P<0.05)$ in Mytilus galloprovincialis than in Posidonia oceanica (Table 4).

Canari presents the highest $\mathrm{Cd}$, Co, $\mathrm{Cr}$ and $\mathrm{Ni}$ concentrations $(P<0.05)$ whereas Livorno shows the highest $\mathrm{Hg}$ concentration $(P<0.05)$ and Porto-Torres the highest $\mathrm{Pb}$ concentration $(P<0.05$; Table 4$)$.

\subsection{Metal bioconcentrations}

To evaluate the efficiency of metal bioaccumulation by Posidonia oceanica, the biosediment factor (BSAF), defined as the ratio between the metal concentration in the organism and that in the sediment (Lau et al., 1998; Szefer et al., 1999), has been calculated for both species (Figure 2). $\mathrm{Cd}$ is the metal which presents the highest BSAF mean and $\mathrm{Cr}$ is the metal with the lowest one (Figure 2). Posidonia oceanica has the highest BSAF mean for all metals except $\mathrm{Hg}$ (Figure 2).

\subsection{Relationship between metals in Posidonia oceanica and in sediment}

There are significant positive relations for $\mathrm{Co}, \mathrm{Cr}, \mathrm{Hg}$ and $\mathrm{Ni}$ concentrations in Posidonia oceanica relative to their concentrations in sediment $\left(r_{\mathrm{Co}_{\mathrm{O}}}=0.81 ; P<0.05-\mathrm{r}_{\mathrm{Cr}}=0.93 ; \mathrm{r}_{\mathrm{Hg}}=0.95\right.$; $\left.r_{\mathrm{Ni}}=0.98 ; P<0.01\right)$. Non significant relations are found in the case of $\mathrm{Cd}\left(\mathrm{r}_{\mathrm{Cd}}=-0.22\right)$ and $\mathrm{Pb}$ $\left(\mathrm{r}_{\mathrm{Pb}}=-0.20\right)$.

Linear regression between concentrations in Posidonia oceanica ( $y$ values) and those in sediment ( $x$ values) is calculated for metals with positive significant correlations. Trace metals can be ordered as follows in terms of the value of their slope $\mathrm{a}: \mathrm{Hg}\left(\mathrm{a}_{\mathrm{Hg}}=0.136\right)>\mathrm{Co}\left(\mathrm{a}_{\mathrm{Co}}=\right.$ $0.134)>\mathrm{Ni}\left(\mathrm{a}_{\mathrm{Ni}}=0.025\right)>\mathrm{Cr}\left(\mathrm{a}_{\mathrm{Cr}}=0.001\right)$.

\section{Discussion}

Canari is identified as the most $\mathrm{Cd}, \mathrm{Co}, \mathrm{Cr}$ and $\mathrm{Ni}$ contaminated location by all the compartments investigated, except sediment analysis of Cd and DGTs analysis of Cr which reveal a maximum value for Livorno (as a reminder: there are no replicates for DGTs). Concerning $\mathrm{Cd}$, high values of $\mathrm{Cd}$ in the north-west of Corsica have already been revealed (Roméo et al., 1995; Andral et al., 2004) and may be explained by a potential source of Cd contamination in the south-west of Corsica (Lafabrie et al., in press) or by a natural phenomenon such as the upwelling of deep waters rich in Cd (Roméo et al., 1995). The fact that no correlation has been found between $\mathrm{Cd}$ concentrations in Posidonia oceanica and in sediment could indicate that $\mathrm{Cd}$ in Posidonia occeanica tissues reflect the $\mathrm{Cd}$ in water column. This hypothesis seems plausible as Lyngby and Brix (1982) reported that Cd concentrations in the eelgrass Zostera marina L. would reflect Cd concentrations in the ambient water. The fact that, in sediment, the maximum value of $\mathrm{Cd}$ is found in Livorno may be related to the presence of a high amount of calcium carbonate grains in the sediment (Petrilli et al., 1979; Ferrara et al., 1989; Balestri et al., 2004) as, in terrestrial environment, it has been suggested that the addition of calcium carbonate to soil may reduce the uptake of some trace metals by plants (KabataPendias and Pendias, 1984; Sanchiz et al., 2001). Concerning $\mathrm{Co}, \mathrm{Cr}$ and $\mathrm{Ni}$, our results are consistent with literature as previous studies mentioned the presence of high levels of these metals near Canari (Andral et al., 2004) and demonstrated the link with the asbestos mine (see in Lafabrie et al., in press). Furthermore, the fact that positive correlations have been found 
between $\mathrm{Co}, \mathrm{Cr}$ and $\mathrm{Ni}$ concentrations in Posidonia oceanica and in sediment would suggest that $\mathrm{Co}, \mathrm{Cr}$ and $\mathrm{Ni}$ in Posidonia occeanica tissues reflect $\mathrm{Co}, \mathrm{Cr}$ and $\mathrm{Ni}$ in sediment.

Livorno is identified as the most $\mathrm{Hg}$ contaminated location by all the compartments investigated. This result may be related to the chemical plant of Rosignano. Indeed, previous studies revealed the presence of a high level of $\mathrm{Hg}$ and of high levels of suspended particulate matter (200-300 mg/l) in the effluents of this plant (Petrilli et al., 1979; Ferrara et al., 1989; Balestri et al., 2004), and it has been reported that $\mathrm{Hg}$ would be mainly associated to particulate matter (Maserti and Ferrara, 1991; Cossa et al., 1997). Moreover, several studies qualified Livorno as an Hg contaminated site (Maserti et al., 1988; Ferrara et al., 1989; Capiomont et al., 2000; Ferrat et al., 2003a). Furthermore, the fact that a positive correlation has been found between $\mathrm{Hg}$ concentrations in Posidonia oceanica and in sediment, as in the studies of Ferrara et al. (1989) and Sanchiz et al. (1999, 2001), would suggest that Hg in Posidonia oceanica tissues reflects $\mathrm{Hg}$ in sediment.

Porto-Torres is identified as the most $\mathrm{Pb}$ contaminated location by all the compartments investigated, except sediment which shows a maximum $\mathrm{Pb}$ value for Livorno. This result may indicate an influence of the Porto-Torres industrial harbour on $\mathrm{Pb}$ contamination as, moreover, recent studies (Baumard et al., 1998, 1999; Escartin and Porte, 1999; De Luca et al., 2004) revealed a general chemical contamination of the Porto-Torres coast. The fact that, as in the study of Malea et al. (1994) and Sanchiz et al. (1999, 2001), no correlation has been found between $\mathrm{Pb}$ concentrations in Posidonia oceanica and in the sediment, would indicate that $\mathrm{Pb}$ in Posidonia occeanica tissues reflects $\mathrm{Pb}$ in the water column. This hypothesis is reinforced when considering laboratory studies which showed that aquatic plants can remove $\mathrm{Pb}$ from the surrounding water (Bond et al., 1988; Axtell et al., 2003). As for $\mathrm{Cd}$, the $\mathrm{Pb}$ maximum value in sediment, found in Livorno, may be related to the presence of high amounts of calcium carbonate grains in the effluents of the Rosignano plant (Petrilli et al., 1979; Ferrara et al., 1989; Balestri et al., 2004) which would reduce the uptake of $\mathrm{Pb}$ by Posidonia oceanica (KabataPendias and Pendias, 1984; Sanchiz et al., 2001).

The DGT technique is considered a useful tool for the evaluation of the marine environment quality (Zhang and Davison, 2001; Manfra and Accornero, 2005; Larner et al., 2006; Stark et al., 2006). Therefore, even if caution must be used in the interpretation of DGTs results (no replicate), it is worth noting that Posidonia oceanica results globally lead to the same conclusions as DGT ones. In the same way, sediment is considered a sensitive human-induced impact indicator (Calmano et al., 1996; Acevedo-Figueroa et al., 2005; Tankere-Muller et al., 2006) and it is thus interesting to notice that Posidonia oceanica results equally lead to the same overall conclusions as sediment results. Finally, Mytilus galloprovincialis, considered a good indicator of trace metals level in the environment (Ostapczuk et al., 1997a, b; Goldberg and Bertine, 2000; Claisse et al., 2001; Webb and Keough, 2002; Andral et al., 2004; Chiffoleau et al., 2005; Funes et al., 2006), presents the same trends as Posidonia oceanica. Therefore, the endemic Mediterranean seagrass Posidonia oceanica, leading to the same conclusions than the water column, the sediment and the recognized biological indicator Mytilus galloprovincialis in terms of metal contamination, can be described as accurate and reliable indicator.

\section{Conclusions}

Posidonia oceanica is often considered as a useful metal bio-indicator (see Capiomont et al., 2000; Pergent-Martini and Pergent, 2000; Campanella et al., 2001; Ferrat et al., 2003a). This assessment is validated in this study by comparing for the first time metal concentrations found in Posidonia oceanica with those found in the water column, in the sediment and in the recognized metal bio-indicator species Mytilus galloprovincialis. Furthermore, this study shows that Posidonia oceanica may have a greater bioaccumulation capacity than Mytilus galloprovincialis for all the metals considered except $\mathrm{Hg}$ and may reflect both contaminations in the water column and in sediment. Several studies suggest employing seagrasses as bioindicators of coastal waters metal contamination (see synthesis in Ferrat et al., 2003b). Therefore, in future, seagrasses, which are widely distributed in the entire biosphere, could be integrated in the setting-up of a general monitoring network as initiated by the European Commission in the Water Framework Directive (2000/60/EC; EC, 2000). 


\section{Acknowledgements}

This study was supported by a grant from the "Collectivité Territoriale de Corse", the MONIQUA Program (INTERREG IIIA European Convention), and the GdR "Gestion des écosystèmes littoraux méditerranéens" between Ifremer and University of Corsica. We wish to thank B. Mimault for diving assistance. The authors are indebted to the reviewers for their fruitful suggestions.

\section{References}

Acevedo-Figueroa, D., Jiménez, B.D., Rodriguez-Sierra, C.J., 2005. Trace metals in sediments of two estuarine lagoons from Puerto Rico. Environ. Pollut. 141, 336-342.

Andral, B., Stanisiere, J.Y., Sauzade, D., Damier, E., Thebault, H., Galgani, F., Boissery, P., 2004. Monitoring chemical contamination levels in the Mediterranean based on the use of mussel caging. Mar. Pollut. Bull. 49, 704-712.

Axtell, N.R., Sternberg, S.P.K., Claussen, K., 2003. Lead and nickel removal using Microspora and Lemna minor. Bioresource Technol. 89, 41-48.

Balestri, E, Benedetti-Cecchi, L., Lardicci, C., 2004. Variability in patterns of growth and morphology of Posidonia oceanica exposed to urban and industrial wastes: contrasts with two reference locations. J. Exp. Mar. Biol. Ecol. 308, 1-21.

Baumard, P., Budzinski, H., Garrigues, P., 1998. Polycyclic aromatic hydrocarbons in sediments and mussels of the western Mediterranean Sea. Environ. Toxicol. Chem. 17, 765-776.

Baumard, P., Budzinski, H., Garrigues, P., Narbonne, J.F., Burgeot, T., Michel, X., Bellocq, J., 1999. Polycyclic aromatic hydrocarbon (PAH) burden of mussels (Mytilus sp.) in different marine environments in relation with sediment PAH contamination, and bioavailability. Mar. Environ. Res. 47, 415-439.

Bernier, P., Guidi, J.-B., Böttcher, M.E., 1997. Coastal progradation and very early diagenesis of ultramafic sands as a result of rubble discharge from asbestos excavations (northern Corsica, western Mediterranean). Mar. Geol. 144, 163-175.

Bond, A.M., Reust, V., Hudson, H.A., Arnup, K.R., Hanna, P.J., Strother, S., 1988. The effects of temperature, salinity and seagrass species on the uptake of lead (II) from seawater by excised leaves. Mar. Chem. 24, 253-260.

Calmano, W., Ahlf, W., Forstner, U., 1996. Sediment quality assessment: chemical and biological approaches. In: Calmano, W., Forstner, U. (Eds). Sediments and toxic Substances. Springer, Berlin, pp. 1-35.

Campanella, L., Conti, M.E., Cubadda, F., Sucapane, C., 2001. Trace metals in seagrass, algae and molluscs from an uncontaminated area in the Mediterranean. Environ. Pollut. 111, 117-126.

Capiomont, A., Piazzi, L., Pergent, G., 2000. Seasonal variations of total mercury in foliar tissues of Posidonia oceanica. J. Mar. Biol. Ass. U.K. 80, 1119-1123.

Castro, H., Aguilera, P.A., Martinez, J.L., Carrique, E.L., 1999. Differentiation of clams from fishing areas an approximation to coastal quality assessment. Environ. Monit. Assess. 54, 229237.

CEDRE, 2004. La lettre du Cedre - février 2004.

Chiffoleau, J.F., Auger, D., Roux, N., Rozuel, E., Santini, A., 2005. Distribution of silver in mussels and oysters along the French coasts : Data from the national monitoring program. Mar. Pollut. Bull. 50, 1719-1723.

Claisse, D., Cossa, D., Bretaudeau-Sanjuan, J., Touchard, G., Bombled, B., 2001. Methylmercury in molluscs along the french coast. Mar. Pollut. Bull. 42 (4), 329-332.

Cossa, D., Martin, J.M., Takayanagi, K., Sanjuan, J., 1997. The distribution and cycling of mercury species in the Western Mediterranean. Deep-Sea Res. 44, 721-740.

Davison, W., Zhang, H., 1994. In situ speciation measurements of trace components in natural waters using thin-film gels. Nature 367, 546-548.

De Luca, G., Furesi, A., Leardi, R., Micera, G., Panzanelli, A., Piu, P.C., Sanna, G., 2004. Polycyclic aromatic hydrocarbons assessment in the sediments of the Porto Torres Harbor (Northern Sardinia, Italy). Mar. Chem. 86, 15-32. 
EC, 2000. Directive 2000/60/EC of the European Parliament and of the Council of 23 October 2000 establishing a framework for Community action in the field of water policy. Off. J. Eur. Communities 43, 1-72.

Escartin, E., Porte, C., 1999. Assessment of PAH pollution in coastal areas from the NW Mediterranean through the analysis of fish bile. Mar. Pollut. Bull. 38, 1200-1206.

Ferrara, R., Maserti, E., Paterno, P., 1989. Mercury distribution in maritime sediments and its correlation with the Posidonia oceanica prairie in a coastal area affected by a chlor-alkali complex. Toxicol. Environ. Chem. 22, 131-134.

Ferrat, L., Gnassia-Barelli, M., Pergent-Martini, C., Roméo, M., 2003a. Mercury and non-protein thiol compounds in the seagrass Posidonia oceanica. Comp. Biochem. Phys. C 134, 147-155.

Ferrat, L., Pergent-Martini, C., Roméo, M., 2003b. Assessment of the use of biomarkers in aquatic plants for the evaluation of environmental quality: application to seagrasses. Aquat. Toxicol. 65, 187-204.

Funes, V., Alhama, J., Navas, J.I., López-Barea, J., Peinado, J., 2006. Ecotoxicological effects of metal pollution in two mollusc species from the Spanish South Atlantic littoral. Environ. Pollut. $139,214-223$.

Giraud, G., 1979. Sur une méthode de mesure et de comptage des structures foliaires de Posidonia oceanica (Linnaeus) Delile. Bull. Mus. Hist. nat. Marseille 39, 33-39.

Girotti, S., Bolelli, L., Fini, F., Monari, M., Andreani, G., Isani, G., Carpené, E., 2006. Trace metals in arcid clam Scapharca inaequivalvis: Effects of molluscan extracts on bioluminescent bacteria. Chemosphere 65, 627-633.

Goldberg, E.D., Bertine, K.K., 2000. Beyond the Mussel Watch - new directions for monitoring marine pollution. Sci. Total Environ. 247, 165-174.

Kabata-Pendias, A., Pendias, H., 1984. Trace elements in soils and plants. CRC Press, Boca Raton, FL.

Kucuksezgin, F., Kontas, A., Altay, O., Uluturhan, E., Darilmaz, E., 2006. Assessment of marine pollution in Izmir Bay: Nutrient, heavy metal and total hydrocarbon concentrations. Environ. Int. 32, 41-51.

Lafabrie, C., Pergent-Martini, C., Pergent, G., 2007. Metal contamination of Posidonia oceanica meadows along the Corsican coastline (Mediterranean). Environ. Pollut., in press.

Langston, WJ, Spence, SK., 1995. Biological factors involved in metal concentrations observed in aquatic organisms. In: Tessier, A., Turner, D.R. (Eds). Metal speciation and bioavailability in aquatic systems. John Wiley and Sons, New York, pp. 407-478.

Lau, S., Mohamed, M., Tan Chi Yen, A., Suut, S., 1998. Accumulation of heavy metals in freshwater molluscs. Sci. Total Environ. 214, 113-121.

Larner, B.L., Seen, A.J., Snape, I., 2006. Evaluation of diffusive gradients in thin film (DGT) samplers for measuring contaminants in the Antarctic marine environment. Chemosphere 65, 811-820.

Lyngby, J.E., Brix, H., 1982. Seasonal and environmental variation in cadmium, copper, lead and zinc concentrations in eelgrass (Zostera marina L.) in the Limfjord, Denmark. Aquat. Bot. 14, 59-74.

Malea, P., Haritonidis, S., Kevrekidis, T., 1994. Seasonal and local variations of metal concentrations in the seagrass Posidonia oceanica (L. ) Delile in the Antikyra Gulf, Greece. Sci. Total Environ. 153, 225-235.

Manfra, L., Accornero, A., 2005. Trace metal concentrations in coastal marine waters of the central Mediterranean. Mar. Pollut. Bull. 50, 686-692.

Maserti, B.E., Ferrara, R., Paterno, P., 1988. Posidonia as an indicator of mercury contamination. Mar. Pollut. Bull. 19, 381-382.

Maserti, B.E., Ferrara, R., R., 1991. Mercury in plants, soil and atmosphere near a chlor-alkali complex. Water Air Soil Poll. 56, 15-20.

Morillo, J., Usero, J., Gracia, I., 2005. Biomonitoring of trace metals in a mine-polluted estuarine system (Spain). Chemosphere 58, 1421-1430.

O'Connor, T.P., 1996. Trends in chemical concentrations in mussels and oysters collected along the US coasts from 1986 to 1993. Mar. Environ.mental Res. 41, 183-200.

Ostapczuk, P., Burow, M., May, K., Mohl, C., Froning, M., Sussenbach, B., Waidmann, E., Emons, H., 1997a. Mussels and algae as bioindicators for long-term tendencies of element pollution in marine ecosystems. Chemosphere 34 (9-10), 2049-2058. 
Ostapczuk, P., Schladot, J.D., Emons, H., Oxynos, K., Schramm, K.W., Grimmer, G., Jacob, J., 1997b. Environmental monitoring and banking of marine pollutants by using common mussels. Chemosphere 34 (9-10), 2143-2151.

Pergent-Martini C., Pergent G., 2000. Marine phanerogams as a tool in the evaluation of marine trace-metal contamination : an example from the Mediterranean. Int. J. Environ. Pollut. 13, 1-6.

Petrilli, F.L., De Renzi, G.P., Palmerini Morelli, R., De Flora, S., 1979. Survey of the pollution in a coastal area of the Tyrrhenian Sea. Aerial photography, physico-chemical and microbiological investigations and mutagenic monitoring. Water Res. 13, 895-904.

Rainbow, P.S., Phillips, D., 1993. Cosmopolitan biomonitors of trace metals. Mar. Pollut. Bull. 26 (11), 593-601.

Roméo, M., Gnassia-Barelli, M., Juhel, T., Meinesz, A., 1995. Memorization of heavy metals by scales of the seagrass Posidonia oceanica, collected in the NW Mediterranean. Mar. Ecol. Prog. Ser. 120, 211-218.

Ronza, A., Carol, S., Espejo, V., Vílchez, J.A., Arnaldos, J., 2006. A quantitative risk analysis approach to port hydrocarbon logistics. J. Hazard. Mater. A 128, 10-24.

Sanchiz, C., García-Carrascosa, A.M., Pastor, A., 1999. Bioaccumulation of $\mathrm{Hg}, \mathrm{Cd}, \mathrm{Pb}$ and $\mathrm{Zn}$ in four marine phanerogams and the alga Caulerpa prolifera (Försskal) lamouroux from the East Coast of Spain. Bot. Mar. 42, 157-164.

Sanchiz, C., García-Carrascosa, A.M., Pastor, A., 2001. Relationships between sediment physico-chemical characteristics and heavy metal bioaccumulation in Mediterranean softbottom macrophytes. Aquat. Bot. 69, 63-73.

Stark, J.S., Johnstone, G.J., Palmer, A.S., Snape, I., Larner, B.L., Riddle, M.J., 2006. Monitoring the remediation of a near shore waste disposal site in Antarctica using the amphipod Paramoera walkeri and diffusive gradients in thin films (DGTs). Mar. Pollut. Bull., doi: 10.1016/j.marpolbul.2006.05.020.

Szefer, P., Ali, A.A., Ba-Haroon, A.A., Rajeh, A.A., Geldon, J., Nabrzyski, M., 1999. Distribution and relationships of selected trace metals in molluscs and associated sediments from the Gulf of Aden, Yemen. Environ. Pollut. 106, 299-314.

Tankere-Muller, S., Zhang, H., Davison, W., Finke, N., Larsen, O., Stahl, H., Glud, R.N., 2006. Fine scale remobilisation of $\mathrm{Fe}, \mathrm{Mn}, \mathrm{Co}, \mathrm{Ni}, \mathrm{Cu}$ and $\mathrm{Cd}$ in contaminated marine sediment. Mar. Chem., doi: 10.1016/j.marchem.2006.04.005.

US Environmental Protection Agency, 2000. Assigning values to non-detected/non-quantified pesticide residues in human health food exposure assessments. Retrieved February 15, 2007, from US Environmental Protection Agency, Office of Pesticide Programs Web site: http://www.epa.gov/pesticides/trac/science/trac3b012.pdf.

Usero, J., Morillo, J., Gracia, I., 2005. Heavy metal concentrations in molluscs from the Atlantic coast of southern Spain. Chemosphere 59, 1175-1181.

Webb, H., Keough, M.J., 2002. Mesaurement of environmental trace-metal levels with transplanted mussels and diffusive gradients in thin films (DGT): a comparison of techniques. Mar. Pollut. Bull. 44, 222-229.

Zhang, H., Davison, W., 2000. Direct in situ measurements of labile inorganic and organically bound metal species in synthetic solutions and natural waters using DGT. Anal. Chem. 72, 4447-4457.

Zhang, H., Davison, W., 2001. In situ speciation measurements. Using diffusive gradients in thin films (DGT) to determine inorganically and organically complexed metals. Pure Appl. Chem. 73, 9-15.

Zoller, U., 2006. Estuarine and coastal zone marine pollution by the nonionic alkylphenol ethoxylates endocrine disrupters: Is there a potential ecotoxicological problem? Environ. Int. 32, 269-272.

Zoller, U., Hushan, M., 2000. The nonionic surfactant pollution profile of Israel Mediterranean Sea coastal aquifer. Water Sci. Technol. 42 (1/2), 429-35. 
Table 1: Analysis of trace metals in the certified reference material Lagarosiphon major. Results are expressed in $\mu \mathrm{g} \cdot \mathrm{g}^{-1}$ dry wt. (mean value $\pm 95 \%$ confidence interval).

\begin{tabular}{|c|c|c|c|c|c|c|}
\hline & $\mathrm{Cd}$ & Co & $\mathrm{Cr}$ & $\mathrm{Hg}$ & $\mathrm{Ni}$ & $\mathrm{Pb}$ \\
\hline $\begin{array}{l}\text { Certified } \\
\text { values }\end{array}$ & $2.20 \pm 0.10$ & & & $0.34 \pm 0.04$ & & $63.80 \pm 3.20$ \\
\hline $\begin{array}{l}\text { Uncertified } \\
\text { values }\end{array}$ & & 4.00 & 26.00 & & 40.00 & \\
\hline Our values & $2.03 \pm 0.01$ & $3.70 \pm 0.20$ & $24.00 \pm 1.00$ & $\begin{array}{l}0 \\
.35 \pm 0.01\end{array}$ & $37.00 \pm 1.00$ & $62.40 \pm 0.40$ \\
\hline
\end{tabular}

Table 2: Metal concentrations in seawater (in $\mathrm{ng} \cdot \mathrm{L}^{-1}$; the location presenting the maximum value is in bold).

\begin{tabular}{lccccc}
\hline & $\mathrm{Cd}$ & $\mathrm{Co}$ & $\mathrm{Cr}$ & $\mathrm{Ni}$ & $\mathrm{Pb}$ \\
\hline Canari & $\mathbf{1 6}$ & $\mathbf{1 7}$ & 152 & $\mathbf{1 3 8 0}$ & 48 \\
Livorno & 6 & 8 & $\mathbf{6 1 6}$ & 197 & 38 \\
Porto- & 9 & 16 & 282 & 378 & $\mathbf{7 5}$ \\
Torres & 9 & & \\
\hline
\end{tabular}

Table 3: Metal concentrations in sediment (mean \pm S.E. in $\mu \mathrm{g} . \mathrm{g}^{-1}$ dry wt. with S.E.: Standard Error; Standard Error $=$ Standard Deviation $/ \sqrt{ } \mathrm{n} ; \mathrm{n}=3$ replicates - the location presenting the maximum value is in bold).

\begin{tabular}{lcccccc}
\hline & $\mathrm{Cd}$ & $\mathrm{Co}$ & $\mathrm{Cr}$ & $\mathrm{Hg}$ & $\mathrm{Ni}$ & $\mathrm{Pb}$ \\
\hline Canari & $0.03 \pm 0.00$ & $\mathbf{5 5 . 3 3} \pm \mathbf{1 4 . 1 9}$ & $\mathbf{1 1 9 4} \pm \mathbf{2 8 2}$ & $0.02 \pm 0.01$ & $\mathbf{1 3 2 5} \pm \mathbf{5}$ & $4.67 \pm 0.67$ \\
Livorno & $\mathbf{0 . 4 0 \pm 0 . 1 0}$ & $7.00 \pm 1.00$ & $85 \pm 17$ & $\mathbf{0 . 5 6} \pm \mathbf{0 . 1 4}$ & $40 \pm 6$ & $\mathbf{4 4 . 5 0 \pm 4 . 5 0}$ \\
Porto- & $0.07 \pm 0.03$ & $2.50 \pm 0.00$ & $9 \pm 4$ & $0.07 \pm 0.04$ & $4 \pm 1$ & $18.67 \pm 2.19$ \\
Torres & & & & &
\end{tabular}

Table 4: Metal concentrations in Mytilus galloprovincialis (M.g.) and Posidonia oceanica (P.o.; mean \pm S.E. in $\mu \mathrm{g} . \mathrm{g}^{-1}$ dry wt.; $\mathrm{n}=3$ replicates - the location presenting the maximum value is in bold).

\begin{tabular}{|c|c|c|c|c|c|c|}
\hline & $\mathrm{Cd}$ & Co & $\mathrm{Cr}$ & $\mathrm{Hg}$ & $\mathrm{Ni}$ & $\mathrm{Pb}$ \\
\hline \multicolumn{7}{|l|}{ M.g. } \\
\hline Canari & $1.82 \pm 0.05$ & $1.43 \pm 0.09$ & $3.00 \pm 0.67$ & $0.09 \pm 0.00$ & $3.67 \pm 0.86$ & $1.17 \pm 0.09$ \\
\hline Livorno & $1.13 \pm 0.05$ & 0.06 & $0.47 \pm 0.07$ & $0.12 \pm 0.01$ & $1.10 \pm 0.10$ & $1.07 \pm 0.09$ \\
\hline $\begin{array}{l}\text { Porto- } \\
\text { Torres }\end{array}$ & $1.77 \pm 0.12$ & $0.83 \pm 0.13$ & $0.43 \pm 0.09$ & $0.10 \pm 0.01$ & $1.37 \pm 0.12$ & $1.43 \pm 0.19$ \\
\hline \multicolumn{7}{|l|}{ P.o. } \\
\hline Canari & $5.38 \pm 0.14$ & $\begin{array}{c}12.07 \pm \\
0.52\end{array}$ & $1.27 \pm 0.23$ & $0.05 \pm 0.00$ & $\begin{array}{c}60.30 \pm \\
3.67\end{array}$ & $1.47 \pm 0.03$ \\
\hline Livorno & $3.39 \pm 0.12$ & $5.73 \pm 0.03$ & $0.27 \pm 0.07$ & $0.13 \pm 0.00$ & $\begin{array}{c}28.90 \pm \\
0.65\end{array}$ & $1.40 \pm 0.25$ \\
\hline $\begin{array}{l}\text { Porto- } \\
\text { Torres }\end{array}$ & $2.10 \pm 0.10$ & $1.70 \pm 0.06$ & $0.20 \pm 0.06$ & $0.06 \pm 0.00$ & $\begin{array}{c}27.47 \pm \\
1.10\end{array}$ & $1.80 \pm 0.00$ \\
\hline
\end{tabular}




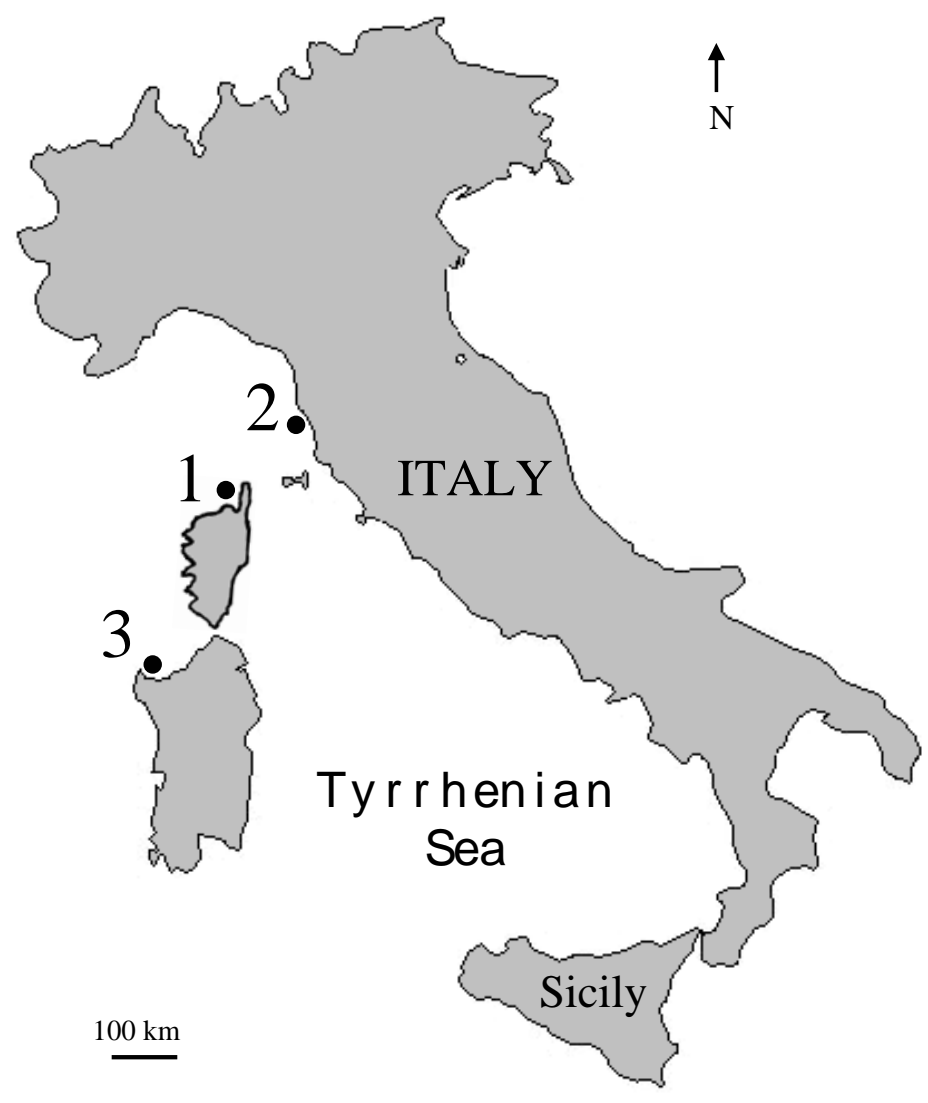

Figure 1: Sampling locations in the north-western Mediterranean. 1: Canari (Corsica, France) -2: Livorno (Toscana, Italy) - 3: Porto-Torres (Sardinia, Italy). 


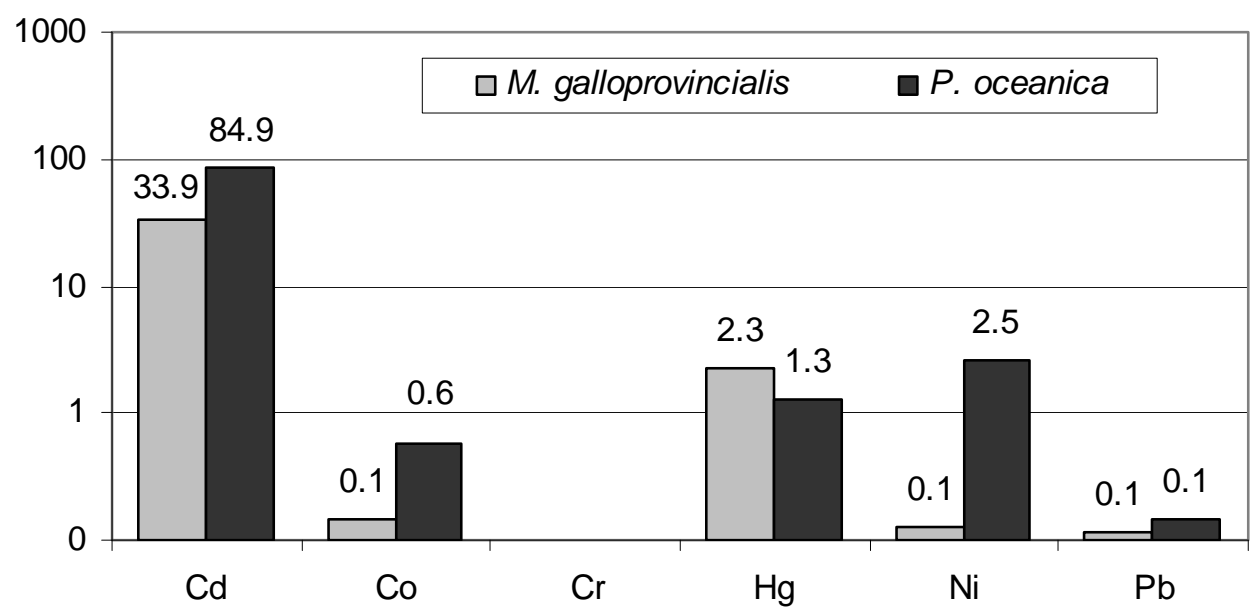

Figure 2: Mean bio-sediment accumulation factor values (BSAF) in Mytilus galloprovincialis and Posidonia oceanica. 